\title{
Toxicological evaluation of submerged liquid culture from Phanerochaete chrysosporium mycelium on human blood cells: cytotoxicity, genotoxicity and oxidative damage
}

\author{
Fatime GEYIKOGLU ${ }^{1}$, Salim CERIG ${ }^{* 1}$, Murat OZDAL ${ }^{1}$, Kübra KOC ${ }^{1}$, Ömer Faruk \\ ALGUR ${ }^{1}$, Gülsah Deniz YILDIZ ${ }^{2}$, Özlem GULMEZ ${ }^{1}$
}

${ }^{1}$ Department of Biology, Faculty of Science, Atatürk University, Erzurum, Turkey

${ }^{2}$ Health Services, Vocational High School, Ataturk University, Erzurum, Turkey

Received: 05 May 2017 - Revised: 11 October 2017 - Accepted: 18 November 2017

\begin{abstract}
Mushrooms produce a variety of bioactive antioxidant secondary metabolites including ectins, polysaccharides, pigments, phenolic compounds, sterols and terpenes. Extracellular and intracellular compounds produced by submerged liquid fermentation are important industrially and economically. Phanerochaete chrysosporium (PC) is the model white-rot fungus that easy cultivation on lignocellulose-containing substrates. $\mathrm{PC}$ can be used as a bioprotein source. Aims of this study were to determine the in vitro antioxidant, cytotoxic and genotoxic effects of hot water extract obtained from PC on human peripheral blood monunuclear cells (hPBMCs). Cytotoxicity was determined by lactate dehydrogenase (LDH) leakeage assay and neutral red (NR). Total antioxidant capacity (TAC) and total oxidant status (TOS) were detected to determine the oxidative damage. Genotoxicity was characterized by micronuclei and chromosome aberrations assays for specify DNA damage. PC $(5-75 \mu \mathrm{g} / \mathrm{ml})$ significantly increased antioxidant capacity and these doses did not cause any significant alterations to cytotoxicity on hPBMCs. The elavated doses of PC $(5-250 \mu \mathrm{g} / \mathrm{ml})$ did not cause increase in genotoxic. Whereas, 250 and $500 \mu \mathrm{g} / \mathrm{ml}$ doses of PC statistically increased TOS levels, NR uptake, LDH release, CA/cell frequency and $\mathrm{MN}$ formation however decreased TAC levels. This study is the first time on cytotoxicity, genotoxicity and oxidative damage of PC on hPBMCs. In conclusion, the consumption of PC can be safe for humans, but it has also exposure period and dose-dependent effects on inducing oxidative damage and toxicity on hPBMCs.
\end{abstract}

Keywords: Phanerochaete chrysosporium, human blood cells, cytotoxic, genotoxic, antioxidant

\section{INTRODUCTION}

A number of studies are performed regarding to the antimicrobial and antioxidant properties of many edible and inedible mushrooms extracts, collected at various habitats and obtained from different types of basidiomycetes [1, 2]. Extracellular and intracellular compounds produced by submerged liquid fermentation are industrially and economically important [3]. Synthetic antioxidants are used at legal limits because they are unhealthy. Natural antioxidants can be nitrogen compounds (amino acids and alkaloids) and phenolic compounds (phenolic acids and flavonoids), pigments represent the main antioxidant components derived from mushrooms [4]. A research had proven the antioxidant activity of PC [5].

\footnotetext{
${ }^{*}$ Corresponding Author E-mail: salimcerig@atauni.edu.tr
} 
It is fundamental that mushrooms must be professionally inspected and their safety and quality approved before being ingested [6]. The uncontrolled mushroom diet can result in overproduction of reactive oxygen species (ROS), which are associated with oxidative stress [7]. ROS is produced in physiological and metabolic periods, and detrimental oxidative reactions may occur in organisms that remove them via enzymatic and non-enzymatic antioxidative reactions. Antioxidant molecules prevent or inhibit detrimental reactions [8]. Serum concentrations of different antioxidant and oxidants can be evaluated in laboratories respectively, however the measurements are time-consuming, labor-intensive, costly, and require complicated techniques. Because the measurements of oxidant/antioxidant molecules separately are not practical and their effects are additive, the total antioxidant capacity of a sample is measured, and this is called TAC. The total oxidative status of a sample is measured and named as TOS $[9,10]$.

Customary, the toxic effects of unknown compounds have been measured in vitro by counting viable cells after staining with a vital dye. The lactate dehydrogenase (LDH) assay is a means of measuring either the number of cells via total cytoplasmic LDH or membrane integrity as a function of the amount of cytoplasmic LDH released into the medium [11]. In addition, the neutral red (NR) assay system is a means of measuring living cells via the uptake of the vital dye neutral red. This assay is rapid, easy to perform, and suitable for handling of large numbers of cultures simultaneously. It can be used for concentration range-finding preexperiments [12]. To assess the oxidative stress-mediated DNA damages, the micronuclei (MN) are a small extra nucleus separated from the main one, generated during cellular division by late chromosomes or by chromosome fragments. $\mathrm{MN}$ is a rapid, sensitive and simple in vitro assay for the detection of micronuclei in the cytoplasm of interphase human lymphocytes [1315]. Moreover, chromosome aberrations (CAs) assay in hPBMCs is the most widely used cytogenetic marker to define the effects of DNA damaging agents [16].

Mushroom extract supplement or a mushroom ingestion can definitely affect the immune system and have an affect on cancer protection or treatment. Therefore, mushrooms are regarded as functional foods and have been in use for decades in folk medicine. However, what remain uncertain are the effects on blood cells. This study has the aim to determine the antioxidant status and cyto-genotoxic effects of hot-water extract of mycelium of the PC on hPBMCs of healthy donors. In this way, we firstly evaluated the effects of PC extract on the cytotoxicity via LDH and NR assays on cultured hPBMCs. We also appreciated the role of this edible mushroom on antioxidant capacity via TAC and TOS analysis and DNA damage determined by CAs and MN assays after PC treatment in cultured hPBMCs.

\section{MATERIAL and METHODS}

\subsection{Chemicals}

All reagents and chemicals were purchased from Sigma Aldrich GmbH (Sternheim, Germany). All other unlabeled reagents and chemicals were of analytical grade.

\subsection{Culture and Storage Condition}

The PC was obtained from Dr. Abdurrahman Dündar (Mardin Artuklu University, Turkey). The strain was preserved on potato dextrose agar (PDA) and malt extract agar (MEA) slants at $4{ }^{\circ} \mathrm{C}$. The microorganisms were subcultured at regular intervals (15 days) to maintain viability.

\subsection{Media Preparation and Fermentation Condition}

The PC was initially grown on PDA medium for 10 days at $25{ }^{\circ} \mathrm{C}$. Submerged fermentation was carried out in $500 \mathrm{~mL}$ erlenmeyer flasks, containing $200 \mathrm{~mL}$ of liquid medium 
(Glucose $20 \mathrm{~g} / \mathrm{L}$, peptone $2 \mathrm{~g} / \mathrm{L}$, yeast extract $3 \mathrm{~g} / \mathrm{L}, \mathrm{KH}_{2} \mathrm{PO}_{4} 1 \mathrm{~g} / \mathrm{L}, \mathrm{MgSO}_{4} 0.5 \mathrm{~g} / \mathrm{L}$,). The inoculated flasks were preserved on a rotary shaker at $150 \mathrm{rpm}$ at $25{ }^{\circ} \mathrm{C}$. After 10 days of growth, the mycelium was recovered from the liquid medium by centrifugation at $3500 \mathrm{~g}$ for $10 \mathrm{~min}$. Next, the obtained mycelia were washed 3 times with distilled water. Cultured mycelia were then dried using oven until constant weight. The mycelia concentration of $15.25 \mathrm{~g} / \mathrm{L}$ was obtained for 10 days fermentation.

\subsection{Preparation of Mushroom Extract}

To obtain hot water extraction, $10 \mathrm{~g}$ dry and powdered mycelial biomass was heated with $100 \mathrm{~mL}$ deionized water for $1 \mathrm{~h}$, centrifuging at $5000 \mathrm{~g}$-force for $15 \mathrm{~min}$ and filtering through Whatman No. 1 filter paper. The dried extract was used directly for analyses of antioxidant components (total phenolic and flavonoid) or redissolved in water to a concentration of 100 $\mathrm{mg} / \mathrm{ml}$ and stored at $4{ }^{\circ} \mathrm{C}$ for further uses.

\subsection{Determination of Total Phenolic and Flavonoid Contents}

The ingradient of total phenols in extract was estimated with the Folin- Ciocalteu reagent, using gallic acid [17]. The total flavonoid ingradient was calculated from a calibration curve using quercetin (QE) as standard [18].

\subsection{Cell Cultures and Treatment}

Blood samples were obtained by venipuncture into syringes containing sodium heparin as anticoagulant from four healthy, non-smoking, female donors (age between 22 - $26 \mathrm{yrs}$ ) and not exposed to any drug therapy or not known mutagenic agent over the past two years. The blood was diluted with the same volume of phosphate buffer solution (PBS) without $\mathrm{Ca}^{+2}$ and $\mathrm{Mg}^{+2}$. Cell-PBS mixture was carefully added onto a Histopaque 1077 (v/v), followed by centrifugation at $400 \mathrm{~g}$ for $30 \mathrm{~min}$ at $20^{\circ} \mathrm{C}$. The cloudy layer (lymphocytes) were aspirated with a pasture pipette and brought into a new tube. The collected fraction was diluted by $1 / 4$ with PBS, mixed carefully and centrifuged (10 min; $300 \mathrm{~g}$-force; $\left.20{ }^{\circ} \mathrm{C}\right)$. This step was repeated twice. The cell number was adjusted to $2 \times 10^{6} / \mathrm{ml}$. After seperation, cells were routinely cultured in RPMI 1640 Media with $2 \mathrm{mM}$ L-glutamine, and were supplemented with $10 \%$ fetal bovine serum, penicillin (100 units $/ \mathrm{ml})$, and streptomycin $(100 \mu \mathrm{g} / \mathrm{ml})$. Cells were maintained in humidified air containing $5 \% \mathrm{CO}_{2}$ at $37{ }^{\circ} \mathrm{C}$ for $24 \mathrm{~h}$ before applying the different treatments. Eleven treatment groups were performed. First group, cells were treated with $10 \mu \mathrm{m}$ final concentration of Mitomycin-C as a positive control (PC) for NR, LDH, MN and CAs assays and $25 \mu \mathrm{m}$ hydrogen peroxide $\left(\mathrm{H}_{2} \mathrm{O}_{2}\right)$ and $10 \mu \mathrm{m}$ ascorbic acid $\left(\mathrm{C}_{6} \mathrm{H}_{8} \mathrm{O}_{6}\right)$ for TOS and TAC analysis, respectively, and then washed by medium. Second group, untreated cells named as a negative control (NC). Other ten groups, cells were treated at 5, 10, 15, 25, 40, 75, 100, 250, 500 and $1000 \mu \mathrm{g} / \mathrm{ml}$ concentrations of hot-water extract from mycelium of the PC before incubation for 24 and $48 \mathrm{~h}$ (Fig.1). The experiments were repeated six times independently for each assay, and values were represented as means \pm standard deviation (SD).

\subsection{Cytotoxicity Assesment}

\subsubsection{NR}

Cell viability after 24 and $48 \mathrm{~h}$ PC treatment was assessed using NR according to the manufacturer's protocol (Neutral Red based Sigma, USA). Absorbance values at $540 \mathrm{~nm}$ for NR (corrected at $690 \mathrm{~nm}$ ) were measured using a microplate spectrophotometer (Bio-RAD Benchmark Plus). An increase or decrease in the number of cells or their physiological state results in a concomitant change in the amount of neutral red dye incorporated by the cells in the culture. This indicates the degree of cytotoxicity caused by PC. 


\subsubsection{LDH Release}

LDH released from damaged cells in culture was quantified using the producer's method (Cell Biolabs CytoSelect ${ }^{\mathrm{TM}}$, USA). The rate of $\mathrm{NAD}^{+}$reduction was determined as an increase in absorbance at $490 \mathrm{~nm}$. The rate of $\mathrm{NAD}^{+}$reduction was directly proportional to $\mathrm{LDH}$ activity in the culture.

\subsection{Oxidant/Antioxidant Status}

\subsubsection{TAC and TOS Analysis}

TAC and TOS assays were carried out in plasma samples obtained from cell cultures for $2 \mathrm{~h}$ by trading available kits (Rel Assay Diagnostics, Turkey).

\subsection{Genotoxicity Assesment}

\subsubsection{CAs}

Blood cell cultures were incubated at $37{ }^{\circ} \mathrm{C}$ for $72 \mathrm{~h}$. Test materials were added after 24 and $48 \mathrm{~h}$ of culture initiation, and colchicine $(0.06 \mathrm{ppm})$ was added to each culture at $2 \mathrm{~h}$ before reaping. Cells were cured with different doses of PC. A negative control (untreated group, in PBS) and a positive control (10 $\mu \mathrm{M}$ mytomycin C, Sigma-Aldrich) were also used for testing the correctness of the assays. The CA test was performed as described by Evans, (1975). 1000 metaphases were investigated for the CA assay per donor (totally 400 metaphases). The mean frequency of abnormal cells and the number of CAs per cell (CA/cell) were computed. The MI (MI: number of metaphases/total interphases and metaphases) was scored by recording the number of metaphases in 1000 cells from each group. MI was evaluated according to the OECD [19].

\subsubsection{MN}

The MN assay was performed using the standard procedure recommended by Fenech [20], with slight modifications according to Surrallés [21]. After 24 and 48 h PC treatment, blood cultures were set up. The test material was added $24 \mathrm{~h}$ after phytohaemagglutinin stimulation. Cytochalasin B (Cyt-B), at a final concentration $6 \mu \mathrm{g} / \mathrm{ml}$ was added at $44 \mathrm{~h}$ after the cultures were established, to arrest cytokinesis of dividing cells. Binucleated lymphocytes were then harvested $72 \mathrm{~h}$ after culture setting. The cells were collected by centrifugation and washed with hypotonic solution $(0.075 \mathrm{M} \mathrm{KCl})$ at room temperature, centrifuged and fixed with a methanol/acetic acid (3:1) solution. This step was repeated twice. Air-dried preparations were made and the slides were coded prior to scoring.

\subsection{Statistical Analysis}

Statistical analysis was performed using SPSS software (version 21, USA). Dunnett t-test (two tailed) was performed in order to compare the frequency of micronucleus cells between negative and positive control. One-way ANOVA and Duncan's test was used to detect whether any treatment significantly differed from each other or controls. Statistical results were made with a significance level of 0.05 .

\section{RESULTS}

\subsection{Total Phenolic and Flavonoid Contents of PC}

In present study, PC were used for quantitative evaluation of the total phenolic contents as gallic acid equivalent (GAE) per gram extract and total flavonoid quantification as quercetin (QE) per gram extract were defined by a colorimetric method. The total phenolic and flavonoid content were found as $4.6 \pm 0.22 \mathrm{mg} \mathrm{GAE} / \mathrm{g}$ extract and $1.2 \pm 0.1 \mathrm{mg}$ QE/g extract, respectively. 


\subsection{Oxidant/Antioxidant Status}

Table 1 presents the comparison of oxidant-antioxidant profiles of PC extracts on cultured hPBMCs. As seen from the Table, 10, 15, 25 and $40 \mu \mathrm{g} / \mathrm{ml}$ doses of mushroom extracts caused important increases of TAC levels and decreases of TOS levels as compared to untreated culture. Likewise, mushroom extracts $(75$ and $100 \mu \mathrm{g} / \mathrm{ml})$ did not cause any changes in TAC and TOS levels on hPBMCs. On the other hand, mushroom extracts caused statistically significant increases TOS levels and decreases TAC levels at concentrations 250, 500 and 1000 $\mu \mathrm{g} / \mathrm{ml}$ in comparison with control values on hPBMCs.

Table 1. TAC and TOS analysis in lymphocytes treated with hot-water extract from mycelium of $P C$

\begin{tabular}{|c|c|c|c|}
\hline \multirow[b]{2}{*}{ Test Substances } & \multirow{2}{*}{$\begin{array}{c}\text { Treatment } \\
\text { Concentration } \\
(\mu \mathrm{g} / \mathrm{mL}), 24 \text { hours }\end{array}$} & \multicolumn{2}{|c|}{ Oxidant/Antioxidant status } \\
\hline & & $\begin{array}{c}\text { TOS (mmol } \\
\mathrm{H}_{2} \mathrm{O}_{2} \\
\text { equiv./L) }\end{array}$ & $\begin{array}{l}\text { TAC (mmol } \\
\text { Trolox } \\
\text { equiv./L) } \\
\end{array}$ \\
\hline Negative Control & Untreated cultures & $10,22 \mathrm{~b} \pm 1.54$ & $5.02 \mathrm{c} \pm 0.44$ \\
\hline Positive Control & $\begin{array}{l}\quad 25 \mu \mathrm{m} \mathrm{H}_{2} \mathrm{O}_{2} \text { for } \\
\text { TOS, } 10 \mu \mathrm{m} \text { L-Ascorbic } \\
\text { acid for TAC }\end{array}$ & $33,5 \mathrm{~d} \pm 4.52 *$ & $12.22 \mathrm{a} \pm 1.26^{*}$ \\
\hline & 5 & $10.21 b \pm 1.55$ & $5.15 c \pm 0.51$ \\
\hline & 10 & $9,63 \mathrm{a} \pm 1.74$ & $7.14 \mathrm{~b} \pm 0.74^{*}$ \\
\hline & 15 & $9,58 \mathrm{a} \pm 1.51$ & $7.51 b \pm 0.43 *$ \\
\hline & 25 & $9,44 \mathrm{a} \pm 1.68$ & $7.23 \mathrm{~b} \pm 0.55^{*}$ \\
\hline Doses of PC $(\mu \mathrm{g} / \mathrm{ml})$ & 40 & $9,25 b \pm 1.58$ & $7.72 b c \pm 0.38$ \\
\hline & 75 & $9,16 b \pm 1.35$ & $7.64 c \pm 0.42$ \\
\hline & 100 & $10,33 b \pm 1.65$ & $6.55 c \pm 0.46$ \\
\hline & 250 & $11,52 b c \pm 2.41 *$ & $4.52 \mathrm{~cd} \pm 0.26^{*}$ \\
\hline & 500 & $12,08 \mathrm{c} \pm 2.22 *$ & $3.91 \pm 0.38^{*}$ \\
\hline & 1000 & $14.36 \pm 2.56^{*}$ & $3.08 \pm 0.29 *$ \\
\hline
\end{tabular}

The results are given as the means \pm SD from six independent experiments; means in the figure followed by different letters $(\mathrm{a}, \mathrm{b}, \mathrm{c}, \mathrm{d})$ present significant differences. ${ }^{*} \mathrm{p}<0.05$ was considered significant according to the control group. Positive control: Ascorbic acid $(10 \mu \mathrm{M})$ and hydrogen peroxide $(25 \mu \mathrm{M})$ in TAC and TOS analysis, respectively.

\subsection{Cytotoxicity}

Lactate dehydrogenase (LDH) assays and neutral red (NR) were used to quantify cell viability in response to PC on hPBMCs (Figures 1 and 2). Cells exposed to 5, 10, 15, 25, 40, 75,100 and $250 \mu \mathrm{g} / \mathrm{ml}$ concentrations of hot-water extract from mycelium of the PC didn't show any important alterations in cell viability for 24 and $48 \mathrm{~h}$, as determined by NR and LDH assays. But, 500 and $1000 \mu \mathrm{g} / \mathrm{ml}$ doses of mushroom extracts showed cytotoxic effect on hPBMCs. 


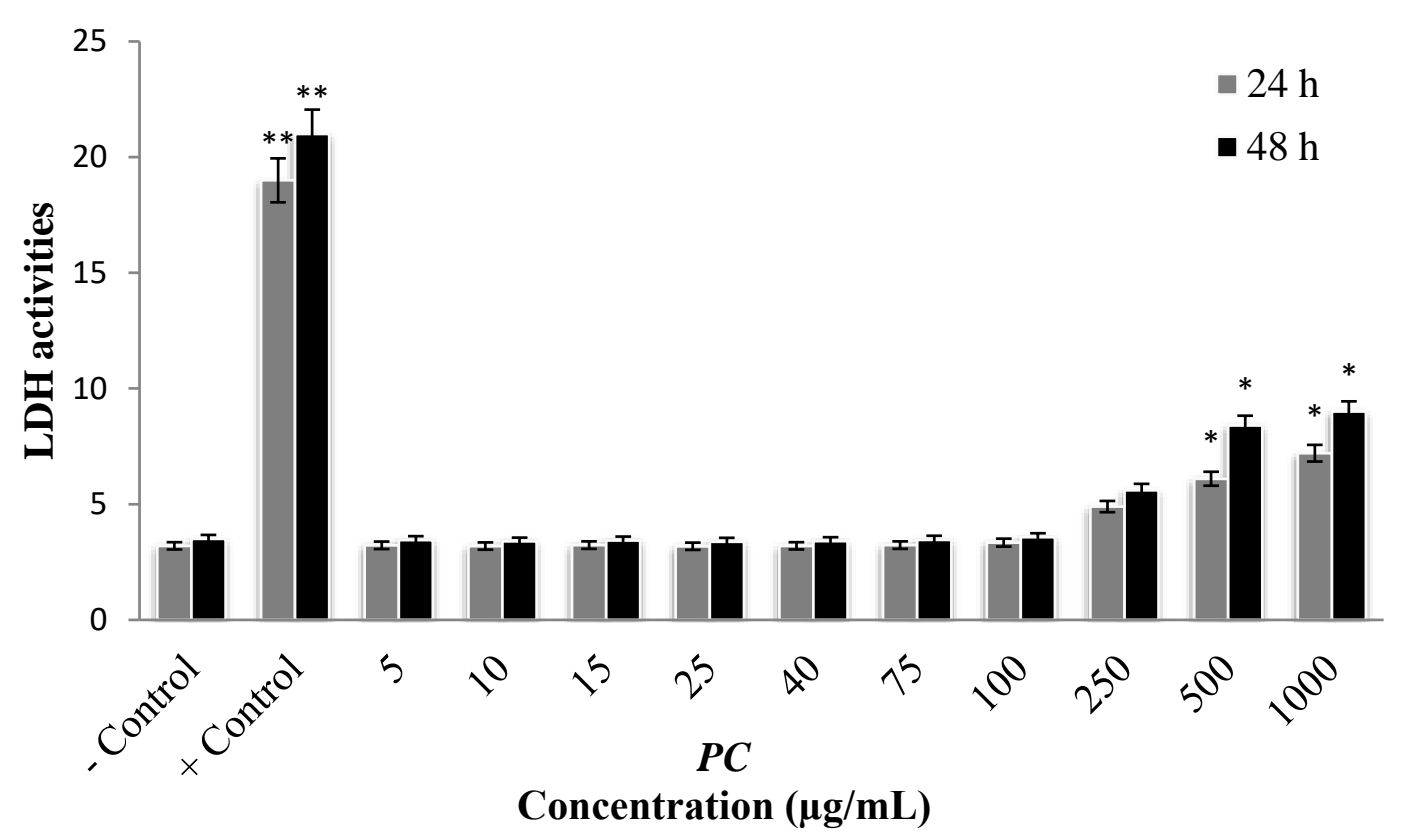

Figure 1. Lactate dehydrogenase (LDH) activity cultured hPBMCs treated with $0-1000 \mu \mathrm{g} / \mathrm{mL}$ of hotwater extract from mycelium of the PC for 24 and 48 hours $(\mathrm{n}=6)$. $* \mathrm{P}<0.05, * * \mathrm{P}<0.01 \mathrm{vs}$. control. (-) Control: untreated cultures, (+) Control: $10 \mu \mathrm{M}$ mitomycin C. The bars shown by different letters are significantly different from each other at a level of $5 \%(n=6)$.

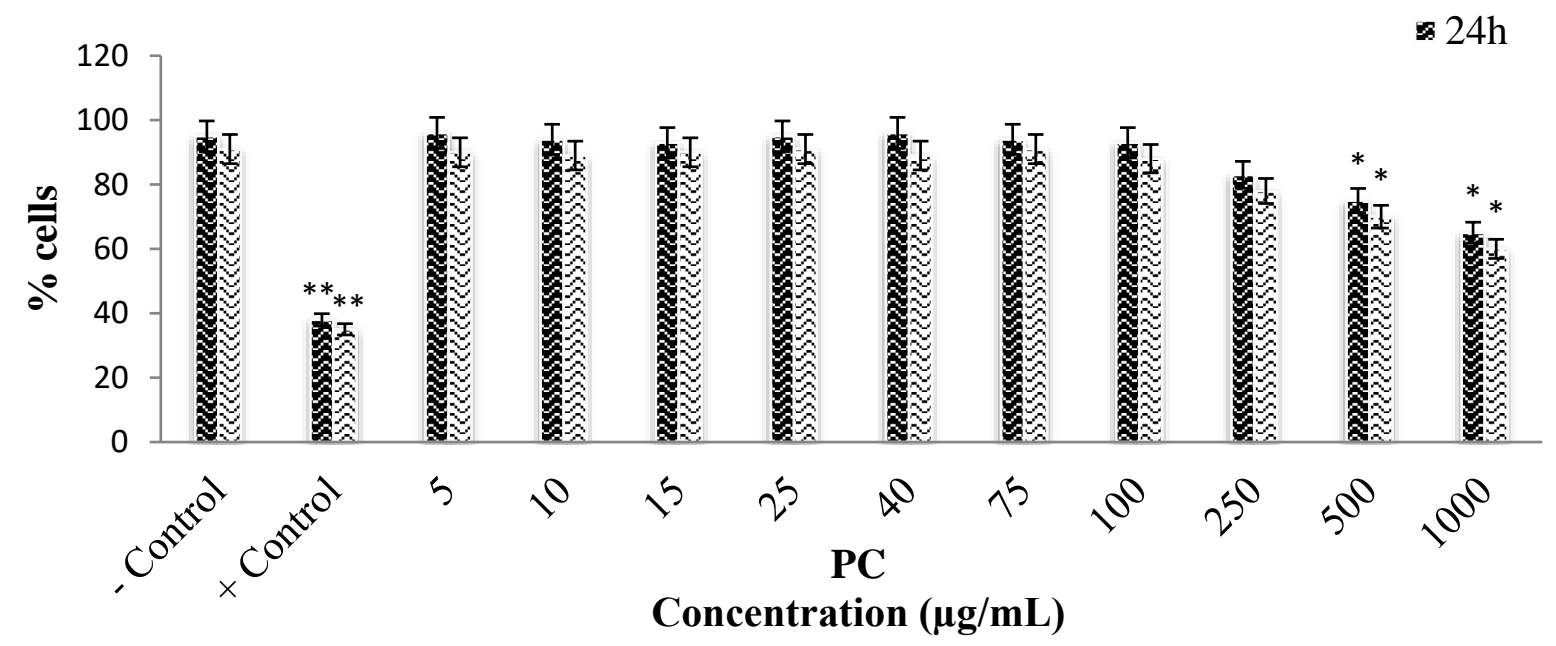

Figure 2. Effects of PC extracts on the viability of hPBMCs at different concentrations $(n=6)$ using neutral red (NR) assay. $* \mathrm{P}<0.05$, $* * \mathrm{P}<0.01$ vs. control. (-) Control: untreated cultures, (+) Control: $10 \mu \mathrm{M}$ mitomycin $\mathrm{C}$. The bars shown by different letters are significantly different from each other at a level of $5 \%(n=6)$.

\subsection{Genotoxicity}

The hot-water extract from mycelium of the PC at concentrations of $0-250 \mu \mathrm{g} / \mathrm{ml}$ did not affect significantly the CAs frequency, compared with the negative control (Table 2). The untreated (negative control) cultures did not show any difference, compared with the controls; this result suggested that PBS has no genotoxic effects. Positive control indicated a significant eleviation of CAs when compared to the negative control. Chromatid and chromosome breaks, sister unions, fragments, chromatid exchanges, dicentric chromosomes and polyploidies were researched in this study and any aberrations were not observed at all concentrations. The 
conclusions showed that PC decreased the MI \% at 500 and $1000 \mu \mathrm{g} / \mathrm{ml}$ doses in depending on time. On the other hand, $0-250 \mu \mathrm{g} / \mathrm{ml}$ concentrations did not affect the MI signicantly.The effects of PC exposure on the frequency of MN formation are shown in Table 2. MN results did not show any statistically significant differences between control and the first eightdoses of mushroom $(0-250 \mu \mathrm{g} / \mathrm{ml})$. On the contrary, the higher doses of mushroom (500 and 1000 $\mu \mathrm{g} / \mathrm{ml}$ ) caused increases of $\mathrm{MN}$ rates.

Table 2. Results of the CAs and the frequencies of MN in lymphocytes treated with hot-water extract from mycelium of PC.

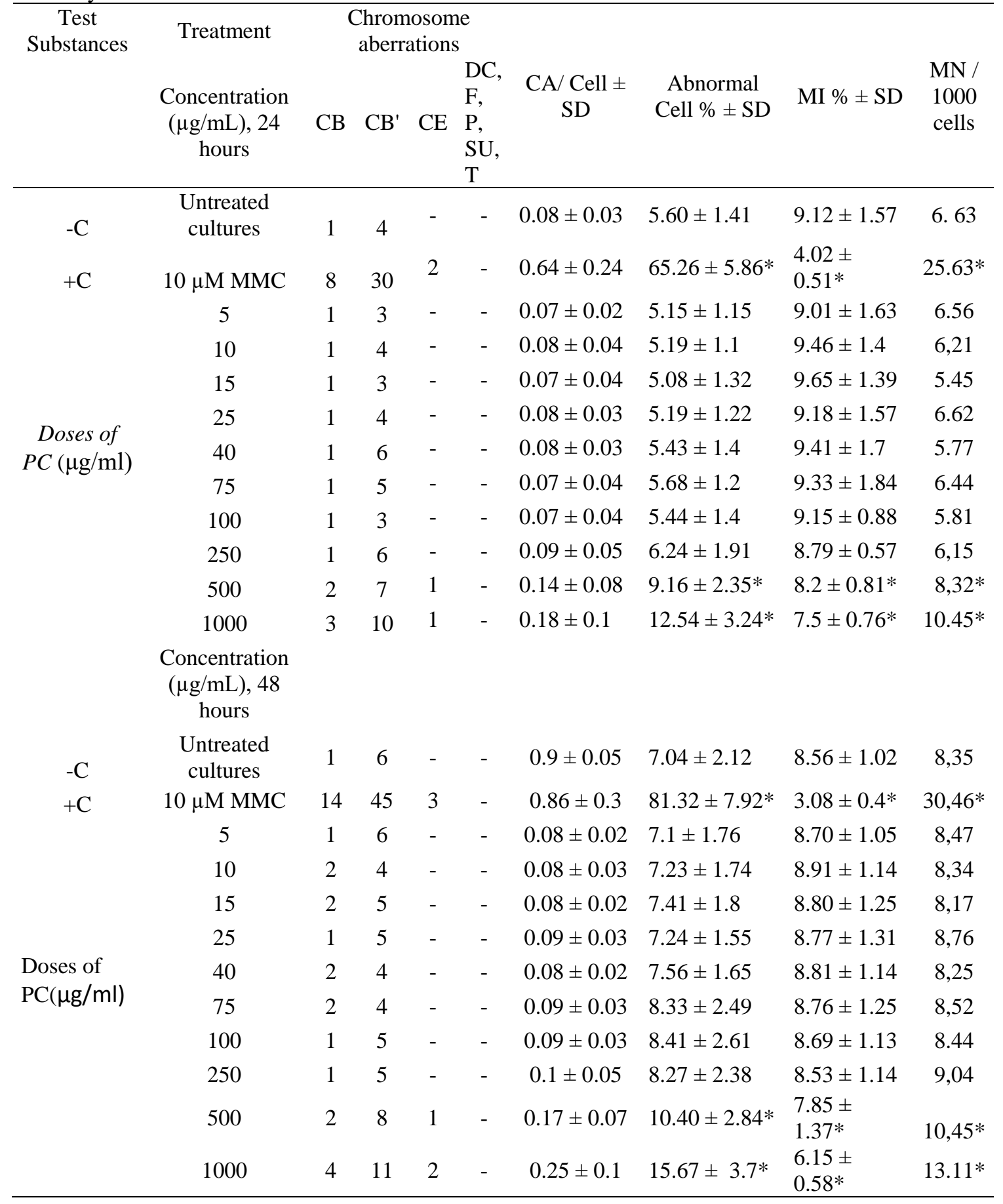

Abbreviations: Negative control (-C), positive control (+C), mitomycin (MMC), chromosome break (CB), chromatid break $\left(\mathrm{CB}^{\prime}\right)$, chromatid exchange $(\mathrm{CE})$, dicentric $(\mathrm{DC})$, fragment $(\mathrm{F})$, polyploidy $(\mathrm{P})$, sister union (SU), translocation $(\mathrm{T})$, standard deviation (SD), mitotic index (MI). Significantly different from the negative control: ${ }^{*} \mathrm{p} \leq 0,05$. 


\section{DISCUSSION AND CONCLUSION}

Phenolic compounds are known as major components of antioxidant in mushrooms. These secondary metabolites also exhibit a wide range of biological effects including antimicrobial, anti-inflammatory, anti-cancer and antihyperglycemic [22; 23; 24]. This study presents the amount of phenolic and flavonoid compenents of hot water extract from mycelia of PC. The total flavonoid and phenolic content were determined as $4.6 \pm 0.22 \mathrm{mg} \mathrm{GAE} / \mathrm{g}$ extract and $1.2 \pm 0.1 \mathrm{mg} \mathrm{QE} / \mathrm{g}$ extract, respectively. According to previous studies at different species, Lee [25] reported that hot water extract from mycelia of $P$. citrinopileatus had $7.85 \mathrm{mg}$ GAE/g. González-Palma [26] reported that hot water extract from mycelia of PC as $4.09 \mathrm{mg}$ $\mathrm{GAE} / \mathrm{g}$ and $0.192 \mathrm{mg} \mathrm{QE} / \mathrm{g}$. This study showed that hot water extract from mycelia of PC has the high amounts of phenolic and flavonoid compenents when compared by above studies. Many studies have confirmed that Pleurotus mushrooms have been valued as nutritional foods and for their medicinal features [27]. Different extracts and bio-materials extracted from oyster mushroom have been used against chronic diseases such as diabetes [28]. According to the literature, in vitro effects of PC extract have still not been studied on hPBMCs of healthy donors. The other aim of the present study was to explore the antioxidant/oxidant, cytotoxic and genotoxic effects of mycelia extract of PC on blood cell cultures. NR and LDH assays were used to evaluate the effects on cell viability and cytotoxicity of PC applications in cultured hPBMCs. The assesment of NR results revealed that PC did not effect to cell viability of blood cells at all doses, in a time and dose dependent, except for 250,500 and $1000 \mu \mathrm{g} / \mathrm{ml}$. Similarly, LDH leakage demonstrated that PC exhibited cytotoxic effects on human blood cells at the mentioned doses. P. abalonus $(500 \mu \mathrm{g} / \mathrm{ml})$ and Auricularia auricula-judae $(250-500 \mu \mathrm{g} / \mathrm{ml})$ reduced cell viability [29]. Our results showed that the cytotoxic effect of hot water extract from mycelia of PC is in good agreement with mentioned studies. Moreover, the low doses of hot water extract of PC $(0-250 \mu \mathrm{g} / \mathrm{ml})$ didn't cause any changes in cell proliferation relative to control in this study.

There are several studies reported antioxidant capacity of Pleurotus cornucopiae [30], $P$. pulmonaris [31], P. citrinopileatus [32] and P. djamor [33]. Findings of this study were in accordance with previous studies on antioxidant properties of other edible mushrooms, since TAC method showed that treatments with mycelium extracts of PC also supported the antioxidant capability of the blood cells in vitro. In present study, the increasing concentrations of PC $(10,15,25,40,75$ and $100 \mu \mathrm{g} / \mathrm{ml})$ significantly increased antioxidant capacity in blood cultures. Also, studied doses of PC did not cause an increase in oxidative stress on hPBMCs. Moreover, the applied concentrations of mushroom significantly decreased TOS levels. It is known that phenolic compounds of edible mushrooms can act as free radical scavengers, hydrogen donators and singlet oxygen quenchers [34]. On this context, phenolic and flavonoidrich hot water extract from mycelia of PC could decrease oxidative stress and protect lymphocytes and monocytes against reactive oxygen species. It is reported that ROS generation decreases mitochondrial membrane potential and increases LDH release due to membrane distribution [35]. In our study, the high doses of PC 500 and $1000 \mu \mathrm{g} / \mathrm{ml}$ ) increased TOS levels and also induced cell injury in a dose-dependent manner, as above indicated by decreased cell viability and increased LDH release.

The MN and CAs could be used to determine the genotoxic effects of the test substances according to previous studies $[36 ; 37]$. We have determined the genotoxic effect of PC on $\mathrm{hPBMCs}$ using MN and CAs assays. This study is the first reported that PC $(0-250 \mu \mathrm{g} / \mathrm{ml})$ has no genotoxic or mutagenic effects on hPBMCs since the observed mean values of the frequency of CAs and MN per cell was not found significantly different from values of the untreated cultures on both cells. In parallel to our findings, a recent study has revealed that edible mushroom such as ethanol extract of Agaricus braziliensis $(50 \mu \mathrm{g} / \mathrm{ml})$ has no genotoxic effects 
[38]. However, the high doses of ethanol extract of this mushroom $(250-500 \mu \mathrm{g} / \mathrm{ml})$ have slightly genotoxic effects on human lymphocytes. As it is supported by this study, the high doses of PC (500 and $1000 \mu \mathrm{g} / \mathrm{ml})$ caused genotoxic effects.

In conclusion, these findings provide evidence on the lack of oxidant/antioxidant status and cyto-genotoxicity of hot water extract from mycelia $\mathrm{PC}$ under our in vitro conditions. As a result of this study revealed that PC at low doses $(0-250 \mu \mathrm{g} / \mathrm{ml})$ on human blood lymphocytes is not genotoxic and also significantly increases the antioxidant capacity of blood. On the other hand, based upon our results, we conclude that PC, if used at higher concentrations (500 and $1000 \mu \mathrm{g} / \mathrm{ml}$ ) have cytotoxic and genotoxic effects and cell damage as due to increased oxidative stress. Hence, the overconsumption of this traditional edible mushroom should be considered. Otherwise, it may cause serious toxic side effects in terms of human health.

\section{Acknowledgement}

The authors are grateful to all volunteers for the blood samples.

\section{Conflict of Interests}

Authors declare that there is no conflict of interests.

\section{REFERENCES}

[1] De Silva, D. D., Rapior, S., Sudarman, E., Stadler, M., Xu, J., Alias, S. A., \& Hyde, K. D. (2013). Bioactive metabolites from macrofungi: ethnopharmacology, biological activities and chemistry. Fungal Diversity, 62(1), 1-40.

[2] Dey, T. B., Chakraborty, S., Jain, K. K., Sharma, A., \& Kuhad, R. C. (2016). Antioxidant phenolics and their microbial production by submerged and solid state fermentation process: A review. Trends in Food Science \& Technology, 53, 60-74.

[3] Dundar, A., Okumus, V., Ozdemir, S., \& Yildiz, A. (2013). Antioxidant properties of cultured mycelia from four Pleurotus species produced in submerged medium. International journal of food properties, 16(5), 1105-1116.

[4] Ozen, T., Darcan, C., Aktop, O., \& Turkekul, I. (2011). Screening of antioxidant, antimicrobial activities and chemical contents of edible mushrooms wildly grown in the Black Sea region of Turkey. Combinatorial Chemistry \& High Throughput Screening, 14(2), 72-84.

[5] Ajila, C. M., Brar, S. K., Verma, M., Tyagi, R. D., \& Valéro, J. R. (2011). Solid-state fermentation of apple pomace using Phanerocheate chrysosporium-Liberation and extraction of phenolic antioxidants. Food Chemistry, 126(3), 1071-1080.

[6] Marcotrigiano, V., De Giglio, O., Quaranta, A., Montagna, M. T., \& Napoli, C. (2013). Mushroom consumption and toxicity, state of the art. Igiene e sanita pubblica, 69(3), 349361.

[7] Yu, S., Wu, X., Ferguson, M., Simmen, R. C., Cleves, M. A., Simmen, F. A., \& Fang, N. (2016). Diets Containing Shiitake Mushroom Reduce Serum Lipids and Serum Lipophilic Antioxidant Capacity in Rats. The Journal of nutrition, 146(12), 2491-2496.

[8] Ibero-Baraibar, I., Azqueta, A., Lopez de Cerain, A., Martinez, J. A., \& Zulet, M. A. (2014). Assessment of DNA damage using comet assay in middle-aged overweight/obese subjects after following a hypocaloric diet supplemented with cocoa extract. Mutagenesis, 30(1), 139-146.

[9] Erel, O. (2004). A novel automated method to measure total antioxidant response against potent free radical reactions. Clinical biochemistry, 37(2), 112-119.

[10] Geyikoglu, F., \& Turkez, H. (2008). Boron compounds reduce vanadium tetraoxide genotoxicity in human lymphocytes. Environmental toxicology and pharmacology, 26(3), 342-347. 
[11] Vergaro, V., Aldieri, E., Fenoglio, I., Marucco, A., Carlucci, C., \& Ciccarella, G. (2016). Surface reactivity and in vitro toxicity on human bronchial epithelial cells (BEAS-2B) of nanomaterials intermediates of the production of titania-based composites. Toxicology in Vitro, 34, 171-178.

[12] Fields, W., Fowler, K., Hargreaves, V., Reeve, L., \& Bombick, B. (2017). Development, qualification, validation and application of the neutral red uptake assay in Chinese Hamster Ovary $(\mathrm{CHO})$ cells using a VITROCELL ${ }^{\circledR}$ VC10® smoke exposure system. Toxicology in Vitro, 40, 144-152.

[13] Turkez, H., Geyikoğlu, F., Dirican, E., \& Tatar, A. (2012). In vitro studies on chemoprotective effect of borax against aflatoxin B1-induced genetic damage in human lymphocytes. Cytotechnology, 64(6), 607-612.

[14] Akbaba, B. G., Turkez, H., Sonmez, E., \& Akbaba, U. (2016). In vitro genotoxicity evaluation of tungsten (VI) oxide nanopowder using human lymphocytes. Biomedical Research.

[15] Liu, N., Guan, Y., Xue, L., Yu, Y., Xiao, J., Chang, Z., \& Guan, W. (2017). Assessment of DNA/Chromosome Damage in the Peripheral Blood Lymphocytes of Workers Exposed to Indium Compounds. Toxicological Sciences, 157(1), 41-49.

[16] Fenech, M., Holland, N., Zeiger, E., Chang, W. P., Burgaz, S., Thomas, P., \& Bonassi, S. (2011). The HUMN and HUMNxL international collaboration projects on human micronucleus assays in lymphocytes and buccal cells-past, present and future. Mutagenesis, 26(1), 239-245.

[17] Vamanu, E. (2012). In vitro antimicrobial and antioxidant activities of ethanolic extract of lyophilized mycelium of Pleurotus ostreatus PQMZ91109. Molecules, 17(4), 3653-3671. [18] Kim, I. S., Yang, M. R., Lee, O. H., \& Kang, S. N. (2011). Antioxidant activities of hot water extracts from various spices. International journal of molecular sciences, 12(6), 4120-4131.

[19] Guideline, O. T. (1997). 475: mammalian bone marrow chromosomal aberration test.

[20] Fenech, M. (1993). The cytokinesis-block micronucleus technique and its application to genotoxicity studies in human populations. Environmental health perspectives, 101(Suppl 3), 101.

[21] Surrallés, J., Antoccia, A., Creus, A., Degrassi, F., Peris, F., Tanzarella, C., \& Marcos, R. (1994). The effect of cytochalasin-B concentration on the frequency of micronuclei induced by four standard mutagens. Results from two laboratories. Mutagenesis, 9(4), 347-353.

[22] Boonsong, S., Klaypradit, W., \& Wilaipun, P. (2016). Antioxidant activities of extracts from five edible mushrooms using different extractants. Agriculture and Natural Resources, 50(2), 89-97.

[23] Kosanić, M., Ranković, B., Rančić, A., \& Stanojković, T. (2016). Evaluation of metal concentration and antioxidant, antimicrobial, and anticancer potentials of two edible mushrooms Lactarius deliciosus and Macrolepiota procera. Journal of food and drug analysis, 24(3), 477-484.

[24] Taofiq, O., González-Paramás, A. M., Martins, A., Barreiro, M. F., \& Ferreira, I. C. (2016). Mushrooms extracts and compounds in cosmetics, cosmeceuticals and nutricosmetics-A review. Industrial Crops and Products, 90, 38-48.

[25] Lee, Y. L., Huang, G. W., Liang, Z. C., \& Mau, J. L. (2007). Antioxidant properties of three extracts from Pleurotus citrinopileatus. LWT-Food Science and Technology, 40(5), 823-833.

[26] González-Palma, I., Escalona-Buendía, H. B., Ponce-Alquicira, E., Téllez-Téllez, M., Gupta, V. K., Díaz-Godínez, G., \& Soriano-Santos, J. (2016). Evaluation of the Antioxidant 
Activity of Aqueous and Methanol Extracts of Pleurotus ostreatus in Different Growth Stages. Frontiers in microbiology, 7.

[27] Gregori, A., Švagelj, M., \& Pohleven, J. (2007). Cultivation techniques and medicinal properties of Pleurotus spp. Food Technology \& Biotechnology, 45(3).

[28] Jayasuriya, W. J. A., Wanigatunge, C. A., Fernando, G. H., Abeytunga, D. T. U., \& Suresh, T. S. (2015). Hypoglycaemic activity of culinary Pleurotus ostreatus and P. cystidiosus mushrooms in healthy volunteers and type 2 diabetic patients on diet control and the possible mechanisms of action. Phytotherapy research, 29(2), 303-309.

[29] Panthong, S., Boonsathorn, N., \& Chuchawankul, S. (2016). Antioxidant activity, antiproliferative activity, and amino acid profiles of ethanolic extracts of edible mushrooms. Genetics and molecular research: GMR, 15(4).

[30] Jiang, J., Liu, H., Li, Q., Gao, N., Yao, Y., \& Xu, H. (2015). Combined remediation of $\mathrm{Cd}$-phenanthrene co-contaminated soil by Pleurotus cornucopiae and Bacillus thuringiensis FQ1 and the antioxidant responses in Pleurotus cornucopiae. Ecotoxicology and environmental safety, 120, 386-393.

[31] Abidin, M. H. Z., Abdullah, N., \& Abidin, N. Z. (2016). Protective effect of antioxidant extracts from grey oyster mushroom, Pleurotus pulmonarius (Agaricomycetes), against human low-density lipoprotein oxidation and aortic endothelial cell damage. International journal of medicinal mushrooms, 18(2).

[32] Lin, S. Y., Chien, S. C., Wang, S. Y., \& Mau, J. L. (2016). Nonvolatile taste components and antioxidant properties of fruiting body and mycelium with high ergothioneine content from the culinary-medicinal golden oyster mushroom Pleurotus citrinopileatus (Agaricomycetes). International journal of medicinal mushrooms, 18(8).

[33] Zhang, J., Meng, G., Zhang, C., Lin, L., Xu, N., Liu, M., \& Jia, L. (2015). The antioxidative effects of acidic-, alkalic-, and enzymatic-extractable mycelium zinc polysaccharides by Pleurotus djamor on liver and kidney of streptozocin-induced diabetic mice. BMC complementary and alternative medicine, 15(1), 440.

[34] Dundar, A., Okumus, V., Ozdemir, S., Celik, K. S., Boga, M., Ozcagli, E., \& Yildiz, A. (2015). Antioxidant, antimicrobial, cytotoxic and anticholinesterase activities of seven mushroom species with their phenolic acid composition. J Hortic, 2, 161.

[35] Yang, Y., Fan, C., Wang, B., Ma, Z., Wang, D., Gong, B., \& Yang, Z. (2017). Pterostilbene attenuates high glucose-induced oxidative injury in hippocampal neuronal cells by activating nuclear factor erythroid 2-related factor 2. Biochimica et Biophysica Acta (BBA)Molecular Basis of Disease, 1863(4), 827-837.

[36] Ryu, T. H., Kim, J. H., \& Kim, J. K. (2016). Chromosomal aberrations in human peripheral blood lymphocytes after exposure to ionizing radiation. Genome integrity, 7.

[37] Guo, X., Ni, J., Xue, J., \& Wang, X. (2017). Extract of bulbus Fritillaria cirrhosa perturbs spindle assembly checkpoint, induces mitotic aberrations and genomic instability in human colon epithelial cell line. Experimental and Toxicologic Pathology, 69(3), 163-171.

[38] Radakovic, M., Djelic, N., Stevanovic, J., Sokovic, M., Radovic, D., Van Griensven, L. J. L. D., \& Stanimirovic, Z. (2015). Evaluation of the antigenotoxic effects of the royal sun mushroom, Agaricus brasiliensis (Higher basidiomycetes) in human lymphocytes treated with thymol in the comet assay. International journal of medicinal mushrooms, 17(4). 321330 . 